\title{
Beba-Bombe Relations: A Study in Socio-Cultural Ties Between Distant Sister Chiefdoms, 1934-2007
}

\author{
Valantine Elize Monoji* \\ PhD Candidate, University of Bamenda \\ *Corresponding Author: Valantine Elize Monoji, PhD Candidate, University of Bamenda, Cameroon
}

\begin{abstract}
In August 1934, Fon Aghanifor passed on and Beba was plunged into a virulent chieftaincy succession crisis which resulted in segmentation, with a faction of malcontented princes bolting out of the land to constitute another settlement called Bombe. Although separated for more than eight decades, they remain a people of the same stock, same ancestral background, linguistic affinities and socio-cultural displays. These parallels condemn them to remain inextricably intertwined. This paper therefore argues that irrespective of the geographical dichotomy, Beba and Bombe remain a people bonded by family nostalgia and tradition. The study relies chiefly on oral sources due to paucity of historical documentation on the study areas.
\end{abstract}

Keywords: Beba-Bombe, relations, socio-cultural, ties, sister chiefdoms

\section{INTRODUCTION}

The world is characterized by human interactions. Since no nation, society community, or person is an island, people get to interrelate either politically, economically, or socially. Africa being a host to thousands of ethnic groups, there is copious evidence of formal relations between the different people in the precolonial, colonial and the post- colonial eras. These relations transcended periods of peace and war with intermediary phases of tensions and negotiations. Thus, societies never existed in seclusion but maintained relations that were either hostile or cordial. In establishing intergroup relations among the Yoruba and Hausa communities in Agege, Gatawa articulates several factors that fashioned the relations between the Hausa and other ethnic communities in Agege submitting that the long established commercial relationship between the Hausa and Yoruba in Agege over the centuries had brought about inter-ethnic marriages evident in the several Hausa prominent personalities in Agegeand Lagos, who are maternally Yoruba. ${ }^{1}$

There is equally abundant evidence of migrant groups that at one point segmented or experienced a split. Such groups, even though live as separate entities are not oblivious of their common ancestry. This is the case with the Chamba of the North West Region of Cameroon who had to split following the death of their leader, Gawolbe with his seven children constituting six to seven Bali villages, all prefixing Bali. ${ }^{2} \mathrm{Nkwi}$ further paints a vivid picture of intergroup relations in Cameroon in his words," the people in the Western "Grassfields" were in daily communion with each other.... They traded mutually, exchanged women, gifts and visits". ${ }^{3}$ Fanso corroborates Nkwi's submission when he asserts that,

Each group was historically and socially linked directly and indirectly to other communities...the network of relations between the diverse groups overlapped from district to district throughout the territory and there were ethnic affiliations and continuities between groups generally located in the same neighbourhood or region.

\footnotetext{
${ }^{1}$ Muhammad Mukhtar Gatawa," Inter-group Relations in Historical Perspectives: A Case Study of Yoruba and Hausa Communities of Agege, Lagos, Nigeria", African Journal of History and Culture 5, No. 9 (2013):111126.

${ }^{2}$ Ndifontah B. Nyamndi, The Bali Chamba of Cameroon: A Political History (Paris: Edition Cape, 1988),12.

${ }^{3}$ P. N. Nkwi, Traditional Diplomacy: A Study of Inter-Chiefdom Relations in the Western Grassfields, North West Province of Cameroon (Yaounde: 1987), 41.
} 
No community was isolated historically, economically or socially from its neighbours. ${ }^{4}$

To Dillon, "the relations between the ethnic groups in this territory were a daily and inescapable reality". All these were meant to ensure peaceful co-existence despite the stiff competition, mutual distrust and sometimes open warfare that characterised the conduct of these activities. The basic premise on which intercommunity relations were based was in the common ancestry of most of the kingdoms and states. Like Warnier stunningly captures"the motivation for intercommunity relations laid in their common descent, covenant, alliances and the belief in God that warranted the oath of alliances". ${ }^{6}$ By virtue of their common ancestry, these communities felt condemned to relate with each other on very peaceful terms because they believed involving in conflicts with their blood relations could attract misfortune. The whys and wherefores that fashioned relations among the different ethnic groups in Cameroon were not very different from those that triggered the relations between Beba and Bombe. Thus, the establishment of socio-cultural ties between Beba and Bombe was a product of ancestral affluences, family nostalgia and the inescapable need to resolve bloodcurdling traditional entanglements.

\section{Situating Beba ANd Bombe In GeO-Historical ConTeXT}

Beba and Bombe are politically and socio-culturally linked but are found in distinct locations in Cameroon. Beba is in Menchum-Valley Sub-Division ${ }^{8}$, Menchum Division in the North West Region of Cameroon. It is a powerful Fondom made up of nine villages with dispersed settlements. These villages include: Shisong, Mbamba, Lower Mbekunyam, Upper Mbekunyam, Fombe, Agah, Sohka, Muala (seat of the Fondom) and Ntadieboh. Beba has a large land surface that is bounded to the North by Oshie, to the North West by Mundum to the West by Mbakong, to the South by Batomo and to the East by Okoromanjang. ${ }^{9}$ (see map I). Bombe that was born out of a segmentation of the Beba community is found in Akwaya Sub-Division, Manyu Division in the South West Region of Cameroon. It is bounded to the North by Assaka, to the South by Messaga, to the West by Essimbi and to the East by Amanavil. ${ }^{10}$ (see map 2).

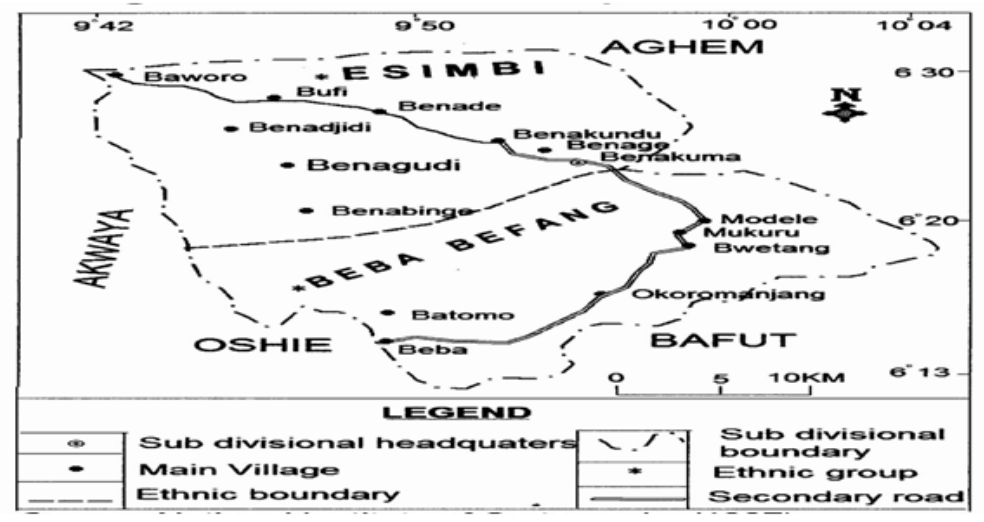

MapI. Location of Beba in Menchum Valley Sub-Division

Source: Adapted from National Institute of Cartography.

\footnotetext{
${ }^{4}$ V.G. Fanso, Cameroon History for Secondary Schools and Colleges Vol. 2: The Colonial and Post-Colonial Periods (London: Macmillan Education Books, 1989),4.

${ }^{5}$ R. S. Smith, Warfare and Diplomacy in Precolonial West Africa (Norwich: Metheun and Co.,1976), 1.

${ }^{6}$ J. P. Warnier, "Precolonial Mankon: The Development of a Cameroon Chiefdom in its Regional Setting" (PhD Thesis, University of Pennysylvania, 1975), 388.

${ }^{7}$ R. G. Dillon, "Ideology, Process and Change in Precolonial Meta Political Organisation (United Republic of Cameroon)" (PhD Thesis, University of Pennyslvannia,1973), 288-9.

${ }^{8}$ It is one of the newly created Sub-Divisions that make up Menchum Division with its Headquarters at Benakuma, Essimbi. This Sub-Division has a surface area of about $878 \mathrm{~km}^{2}$ with a population of about $23,798(1987)$ and a population density of 30 people per $\mathrm{km}^{2}$. The Sub-Division is located to the South West of Menchum Division and is made up of six villages. These villages include: Beba, Befang, Modele, Mukuru, Okoromanjang and Batomo.

It is bordered to the North East by Wum Central Sub-Division, to the South by Oshie and to the South East by Bafut Sub-Division.

${ }^{9}$ Ad 19, file no. 3434, Report on the Reorganization of the WumBefang and Beba tribes in the Wum Native Authority Area Bamenda Division,1934, National Archives Buea(NAB).

${ }^{10}$ File no. D 1270/s.4, Administrative Re-organization Akwaya Sub District, 1963, NAB.
} 


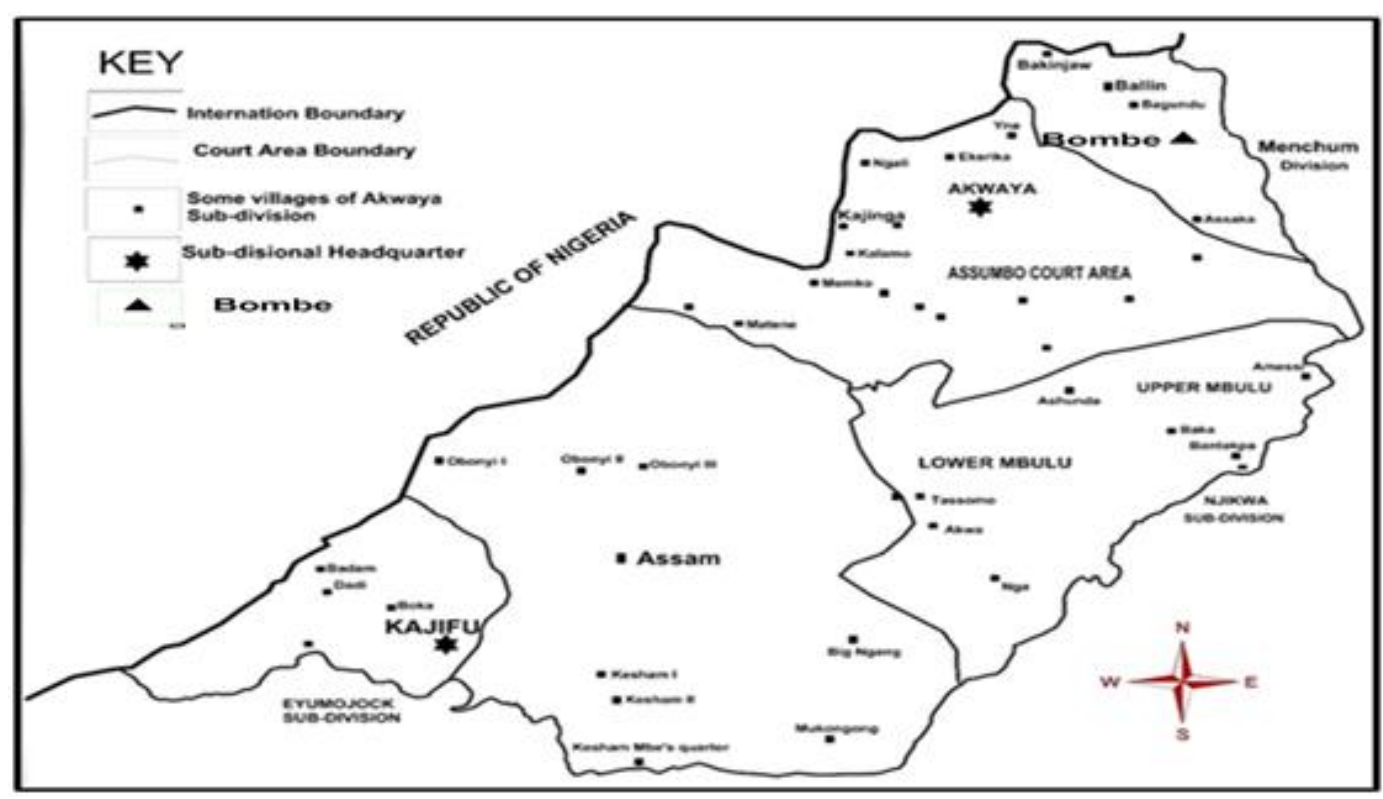

Location of Bombe in Akwaya Subdivision

Source: Adapted from National Institute of Cartography

\section{THE BEBA ChIEFTANCY ROW: BIRTH OF BOMbE}

Before 1937 the polity known today as Bombe was non-existent. It was born out of a succession crisis that cropped up following the death of the then Fon of Beba, in the person of Aghanifor. He died on August 6, 1934 and it was expedient that a replacement be made in accordance with prescribed traditional norms. ${ }^{11}$ It is important to accentuate the fact that succession in Beba like in every other community in the North West Region of Cameroon had prescribed traditional modalities. Nevertheless, in general terms, the word in Beba meant assuming total control of everything that belonged to the deceased Fon including his estate and wives.

In Beba, when a chief was in fear of death, he consulted his elders through the Kpeifor council and informed them which of his sons he wished to succeed him. Unless there were some very tangible reasons, his choice was usually accepted. ${ }^{12}$ If he died suddenly without haven nominated a successor the choice lay with the kingmakers. ${ }^{13}$ Thus, from the establishment of Beba succession had followed the descendants of Angobo, the pioneer Fon. When Fon Agha nifor passed on it remained nonnegotiable that one of his sons would succeed. To avoid any potential squabbles in his absence, Fon Aghanifor had chosen Mathie Ntze Nkimba as his heir and his choice was unanimously accepted by the Bekpop (kingmakers). Beba was however caught in a web of uncertainty when the Fon passed on while Mathie Ntze was still a minor. In keeping with Beba traditional holdings and British colonial administrative demands, it was unacceptable for a minor to rule.

Mindful of the traditional stipulations on succession, the Bekpop were supposed to cede the throne to one of the Fon's brothers to rule as regent until Mathie Ntze was ripe enough to assume leadership. But, immediately after the death of Aghanifor, the Bekpop handpicked Nformineh Tabasa one of the Fon'ssons who though seemed to possess some laudable leadership attributes was, according to the discontented princes, by all honesty and sane judgment not supposed to be appointed chief. Though without any substantial empirical evidence, this supposed fraudulence is attributed to constant gifts of bush meat supplied to the Kingmakers by Nformineh Tabasa who was prolific in the hunting of game. ${ }^{14}$ The Kingmakers' choice of NforminehTabasa was however, surreptitiously wrapped in the smokescreen of bravery and bigheartedness.

It was not long after the hint of preference for NforminehTabasa that to the chagrin of some of the princes, the Bekpop (kingmakers) took him to the Kpeifor house and began the one-month traditional

\footnotetext{
${ }^{11}$ Interview with Henry Angobo Fondeh, MualahBeba, September 20, 2015. Fon of Beba, age 44.

${ }^{12}$ Interview with Frederick Mome, Mutengene, August 10, 2017. Farmer, age 92.

${ }^{13}$ Interview with Pius Awambeng, Upper Mbekunyam, September 10, 2017. Farmer, age 76.

${ }^{14}$ Interview with Frederick Mome, Mutengene, August 10, 2017. Farmer, age 92.
} 
preparation process of to-be Fons, even with prior knowledge of the rightful heir, in the person of Mathie Ntze. It should be re-echoed that, Mathie Ntze was the heir who had been chosen by Aghanifor and unanimously accepted by the kingmakers. It would therefore be astounding to Asanji the first son of the deceased Fon and some positive minded princes that the deceased's decision was flouted with impunity by the kingmakers upon his death.

The decision of the kingmakers was therefore given a negative twist by Asanji. He was a man of modest character with an unflinching desire to uphold the traditions and custom of the people. In collaboration with the other disgruntled princes, the Kpeifor house was stormed, and NforminehTabasa was brought out and brutally tortured. Being aman of immeasurable courage who had nurtured an unbridled determination to be chief, Nformineh Tabasa channelled his grievances to the British colonial authorities for redress and they immediately reacted to it. ${ }^{15} \mathrm{~A}$ team was set up to probe into the issue. After the necessary findings were conducted, the appointment of Nformineh Tabasa as chief of Beba was approved by the Resident in May 1935, following a report and recommendation from an Administrative officer. ${ }^{16}$ The approval of NforminehTabasaas Fon by the Resident could not put an end to the crisis, as Tabasa's half-brothers dismissed it with every degree of determination. They did not only refuse to recognise him, but he was indefinitely banished from the land. ${ }^{17}$

In May1935, the District Officer (D.O) proceeded to Beba to install the new Fon who had been approved by the Resident in the same month of the same year. After summoning a series of meetings, all forms of unconcealed opposition against Nformineh Tabasa were withdrawn and the principal rival candidate, Mathie Ntze, was freely elected to accompany the District Officer to Bamenda and attend the Government School Up-Station. ${ }^{18}$ This in a way contributed enormously to the removal of the last vestiges of overt opposition to Nformineh Tabasa and he was duly enthroned by the D.O.

The enthronement of Nformineh Tabasa as Fon of Beba though not met with any explicit resistance left somedisgruntledprinces fuming in despair and grief. Peace was threatened in Beba but all attempts to avert the situation and arrest any move that could lead to a breakup ended in a fiasco as the discontented population led by Asanji was ready to desert the area after over a year of acute turbulence in the community. ${ }^{19}$ Two days after the coronation of NforminehTabasa, this faction of princes mobilised at the compound of Asanjiwith their wives and children and took off. Among those who left were AsanjiAghanifor, ForbaAghanifor, AgforkpuAghanifor, NkissapAghanifor, MomeAghanifor, NfornsorAghanifor, AkassalaAghanifor, Ndifor Tom Aghanifor, Joseph AkpatohAghanifor, MantohAghanifor, David MangweshiAghanifor, Marcus Aghanifor and TitaAghanifor. ${ }^{20}$ It was a murky moment in Beba where people sat and watched their family members move out of the land.

However, although many were left in a gloom, the segmentation was exuberantly received by some members of the Beba community because though the times were belligerent with leaders of his calibre being indispensable, Aghanifor's rule was excessively autocratic and this inadvertently made the royal family too powerful. ${ }^{21}$ Considering the fact that Aghanifor's authority was unchallengeable and his decisions unquestionable, many in the Beba community looked at him with sheer disdain. ${ }^{22}$ The autocratic nature of Aghanifor was explicated in the fact that, before 1931 when he reconciled with the elders of Beba, for over two decades, he had ruled without the council of elders. ${ }^{23}$ Secondly, he and his children were noted for forcefully taking most of the beautiful ladies in the village including people's wives. ${ }^{24}$ All these had instilled a feeling of distrust towards the royal family. The

\footnotetext{
${ }^{15} \mathrm{Cb} 1934 / 1$, annual report Bamenda division 1934-1935, BNA.

16 Ibid.

${ }^{17}$ Interview with Frederick Mome, Mutengene, August 10, 2017. Farmer, age 92.

${ }^{18} \mathrm{Cb}$ 1934/1, Annual Report Bamenda Division 1934-1945, BNA.

${ }^{19}$ Interview with Isaiah Agha, Bombe, August 22, 2015. Farmer, age 90.

${ }^{20}$ Interview with Gabriel AbinyamForba, Bombe, August 20, 2015. Farmer and member of the Bekpopsociety in Bombe, age 94.

${ }^{21}$ Ad 17, file no.4583A, Assessment report on the Wum Native Authority Area of Bamenda Division, 1932, NAB.

${ }^{22}$ Anonymous informant.

${ }^{23}$ File no. 772/22, Wum Assessment Report, 1932, NAB.

${ }^{24}$ Interview with Frederick Mome, Mutengene, August 10, 2017. Farmer, age 92.
} 
segmentation was therefore greeted by some dissatisfied individuals with euphoria. They saw it as a disguised attempt by the gods to weaken the royal family. Hence, while those who were sympathetic to the royal family had their minds crowded with pathetic sobs, to the discontented masses, the breakaway of the princes did not seem to perturb them in the least.

\section{THE JOURNEY TO BOMBE}

When the splinters left Beba, some of them found solace at Batomo a neighbouring village to Beba while Marcus Aghanifor, AkassalaAghanifor and David Mangweshi moved to Bamenda and TitaAghanifor to Kumba. ${ }^{25}$ Before arriving at Botomo, their animosity for NforminehTabasa (the new Fon) and his supporters pushed them into taking an "egg oath" at the Ntadieboh hill bordering Beba and Batomo. The "egg oath" was geared towardsa complete annihilation of any future relationship with the Beba people. To them since MathieNtze had been denied his rights, there was no justification for any future interactions with Beba. The oath was backed by certain declarations that were spiritually binding on the breakaway population (later Bombe). This singular event would later prove to be nightmarish to both communities and would present itself as the nucleus of their relations.

After leaving Batomo, the breakaway Beba population later perched at Assaka for about two years. Once more, due to internal wrangling, the breakaway population had to leave Assaka upon the request of the District Officer for Akwaya. The splinters finally met the Messaga people who in 1937 apportioned them land for the establishment of a settlement. It was a vast uninhabited piece of land. The eventual resettlement of the splinters at Messaga marked the birth of a new clan. The place was baptized Bobeh meaning "people's children" but the name was distorted by the colonial administration to read "Bombe" an error that has lingered till this day. ${ }^{26}$

\section{Beba-Bombe Relations in the ERA OF SEgmentation}

The period between 1935 and 1937 marked the first phase in the evolution of the relations between Beba and Bombe after the segmentation. The relations during this period were lukewarm, strained and mired by mutual mistrust. The bitterness that was associated with the loss of the throne, eventually leading to the movement of the princes entrenched a paralysing fear within the entire Beba community leaving the royal family with the impression that the breakaway population would stage a comeback. They envisaged a coup against the Fon. This created tension and panic in Beba. In fact, it is stated that, even after the coronation of NforminehTabasa, the District Officer still stationed police officers in Bebafor over a month to provide ample security and protection to the newly installed Fon. $^{27}$

However, by 1937, the situation came to normalcy in the community on the part of the commoners. But, the royal homestead remained very suspicious of the breakaway population. Traces of fear only fully melted by 1941 when it became known that the breakaway faction had secured a comfortable settlement for themselves. Again within this period MathieNtzeNkimba who was a potential threat to the throne died through poisoning. The establishment of a settlement and the death of MathieNtzeNkimba signalled an end to fear in the Beba community, particularly the royal family. The news of the death of MathieNtze was a fatal blow to the face of the Bombe people who even at the point of exit, were still optimistic about the possible return of MathieNtze in Beba to assume the throne.

\section{BEGINNING OF BUDDING TIES BETWEEN BEBA AND BOMBE}

In the early periods of the segmentation, socio-cultural relations were strained partly due to the "egg oath" though the poor relationship that characterized the two groups was not to last forever. The people gradually began re-establishing ties felt mostly in intermarriages, family interactions and cultural exhibitions. Marriage for instance, was a revered institution in Beba and Bombe. In these communities, a woman was considered as the very first asset that any father was to give his male child. ${ }^{28}$ It was therefore a common practice for parents to get the very first wives for their male

\footnotetext{
${ }^{25}$ Interview with Frederick Mome, Mutengene, August 10, 2017. Farmer, age 92.

${ }^{26}$ Interview with Daniel Mangoh, Bombe, August 20, 2015. Farmer and member of kpeifor Society in Bombe, age 85 .

${ }^{27} \mathrm{Cb}$ 1934/1, annual report Bamenda division 1934-1935, BNA.

${ }^{28}$ Interview with Daniel Mangoh, Bombe, August 20, 2015. Farmer and member of kpeifor Society in Bombe, age 85 .
} 
children after which the boy could get married to as many other women as possible if he so desired. In Beba and Bombe, polygamous marriages were highly emphasized. This was because of the economic and social significance that was attached to the practice. It was normal to hear the people say $m a$ zohmangiehmeaning "I have bought a wife" ${ }^{29}$ The more women and children a man possessed, the more the manpower to cultivate farmlands and the proceeds went to the pocket of the man. This made monogamy unfashionable and reserved for very poor, lazy and unsuccessful men. Polygamy was deep-seated in Beba so that in some cases, woman proposed their co-wives to their husbands. ${ }^{30}$

Women were a symbol of continuity not only of the family lineage but also of the ethnic group. Marriage therefore acted as a formidable force behind the establishment of close ties between Beba and Bombe. The need to marry from the ethnic group necessitated people from both communities to get wives from within these localities considered as those that could preserve family secrets. ${ }^{31}$ This came in the 1940s, a period when the Bombe people had already fully established at their present- day site. Some of the people who had left Beba came back in search of wives and others from Beba also trekked to Bombe in search of beautiful ladies. Tragically, the ladies who got intermarried either remained barren or in most cases died. This heartache later became an issue of considerable concern to both communities. The awful situation continued unabated until 1980 when after consultations with the nforbatrallah (chief priest) it was revealed that the misfortunes were a product of the egg oath. ${ }^{32}$ Swift measures were taken, and cleansing rights were performed at the Beba Royal Palace with Beba and Bombe notables in attendance, making interactions more convenient for both communities.

With the understanding that the people could freely intermarry without any unpleasant outcome, intermarriages were further intensified. It is evident that there hardly existed a family in Bombe without relatives in Beba and vice versa. There existed relatives in the likes of uncles, aunts, cousins, nephews, to name but these. Thus, intermarriages went a long way to strengthen ties between the two groups. It is interesting to note that there existed people in Beba and Bombe who were njindia (successors) to compounds in either of the communities. In a lengthy discussion with William Forba an indigenous Bombe, he indicated that, he was from Bombe but an heir to a compound in Beba. Thus, he was compelled to move to Beba from time to time to drink from the ntohlah (traditional cup) ${ }^{33}$ The cup was one of the key assets inherited by any successor in both communities. Believed to possess the powers of the ancestors, the cup was used to pour libations and to perform other traditional rites. ${ }^{34}$ The custodian of the traditional cup could communicate with the ancestors and act as an intercessor between the living and the dead. In case of ill health, difficulties of delivery, and other misfortunes, the traditional cup was used by the successor for cleansing. For details on the traditional cup and some of its utilities see (pic I).

\section{PictureI. Illustrating a keeper of the Traditional cup}

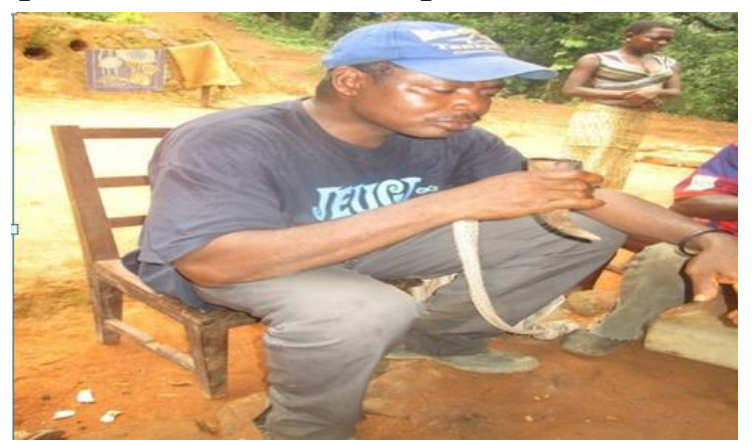

Source: Author's collection, Valentine Elize Monoji, Lower Mbekunyam, September 10, 2017.

\footnotetext{
${ }^{29}$ Interview with Alphonse Fonki, Mbekunyam, September 12, 2015. Farmer, age 77.

${ }^{30}$ Interview with Beatrice Forba, Bombe, August 23, 2017. Farmer, age 64.

${ }^{31}$ There is that notion among the Beba people that intra-ethnic marriages are most preferable. They base their argument on the premise that these type types of marriages enhance family secret. The belief goes further that intra-ethnic marriages are more solidified and protected than any other since the couple see themselves not only as husband and wife but equally as brother and sister. Thus, minor quarrels and differences could easily be resolved but if proves otherwise it could be referred to the village making divorce very rare.

${ }^{32}$ Interview with Beatrice Forba, Bombe, August 23, 2015. Farmer, age 64.

${ }^{33}$ Interview with William Forba, Alakuma- Bamenda, January 20, 2018. Teacher, age 58.

${ }^{34}$ Interview with Patrick Nkwenti Agha, Mbekunyam, September 22, 2015. Farmer, age 60.
} 
The picture above was taken in Beba specifically at Bafui, a quarter in Lower Mbekunyam. The event took place at a funeral ceremony which Bombe people equally attended. Libation was aimed at appeasing the ancestors to continue protecting the family members from premature death. It was a traditional exercise which involved all family members irrespective of whether you were from Beba or Bombe. At every funeral, all family members were expected to drink from the cup to attract the blessings and protection of the ancestors before leaving the funeral ground. These people highly respected the custodians of family cups because of the mystery attached to it and the cup was of immense importance in times of trouble in the family. ${ }^{35}$ In fact, the Njindia(successor) was a reputable figure in the administration of family affairs because he formed a mediating link between the family and their ancestors, by performing rituals and sacrifices to the dead, on behalf of the living through libations with the cup. ${ }^{36}$

Beba custom did not allow for the cup to leave the family residence. This invariably compelled the successor to stay back and take appropriate care of it. In situations where the successor could not stay in the village or at the family residence (as the case with William Forba) ${ }^{37}$, one of his brothers or family members that was based at the family compound was delegated to take care of the cup ${ }^{38}$ But, even at that the successor made sure he visited home at least once a year. Thus, it is against this background that William Forba emphasized that he had the responsibility to visit Beba at least once a year to keep the cup wet ${ }^{39}$.

The people were equally noted to have attended various ceremonies in both villages. This was the case especially with death ceremonies. Once cases of death cropped up, the family members directly implicated and other sympathizers attended such ceremonies. ${ }^{40}$ Within these communities, there were different classifications of death and the nature determined the type of burial rites that were performed. One of the categories of death constituted those who died at old age. This type of death was celebrated with an elaborate banquet. The deceased was considered to have gone to rest with his ancestors after fulfilling his or her mission on earth. ${ }^{41}$ It was this type of death that attracted many people from both communities and the celebrations were often grander with members of both communities actively participating in cultural displays like singing and dancing. ${ }^{42}$ The fenbwere, a lament whose primary theme was death was the most emphasized song at funerals. Fenbweresongs were usually composed from the lament of a mourner who mourned a departed loved one. ${ }^{43}$ The ndo'oto was a complimentary dance that came with fenbwere during funerals. This involved masquerades and the preparations were more elaborate. ${ }^{44}$ See (PicII) for details on funeral celebration in Beba.

\footnotetext{
${ }^{35}$ Interview with Regina Mundi, Bombe August 23, 2015. Farmer, age 76.

36 Interview with Peter Monoji, Konge, September 5, 2018. Farmer, age 76.,Grace NgwebiNdeh, "Communicative and Educative Devices in a Traditional African Society: The case of Beba(MA Dissertation, University of Buea, 2002), 42.

${ }^{37}$ William Forba lives in Bamenda Town specifically at Alakuma. With his busy schedule at work, it became inescapable for him to give the latitude to another family member to be drinking with the cup from time to time. The argument is that the ones you keepthe cup without constantly pouring palm wine in it, calamity might face the family.

${ }^{38}$ Interview with William Forba, Alakuma-Bamenda, January 20, 2018. Teacher, age 58.

${ }^{39}$ Wetting the cup simply means drinking palm wine from the cup. The effect is always disastrous each time the cup is abandoned. Drinking from the cup was a sign of remembering the departed. Therefore, each time the cup went for long without wine the interpretation was that the deceased had been forgotten. No BebaNjindia dared to neglect the cup for fear of facing the wrath of the departed.

${ }^{40}$ Interview with AnthoniaNyambi Bombe, August 24, 2015. Farmer, age 86.

${ }^{41}$ Interview with Mary Ngendo Bombe, Ngendo, August 21, 2015. Farmer, age 84.

${ }^{42}$ Interview with Margaret Tibah Bombe, August 21, 2015. Farmer, age 82.

${ }^{43}$ Regina Mundi, Bombe August 23, 2015. Farmer, age 76.

${ }^{44} \mathrm{Ngwebi}$, "Communicative and Educative Devices, 42.
} 
PictureII. Illustrating ndo'oto performing in a funeral at Bafui-Mbekunyam, Beba

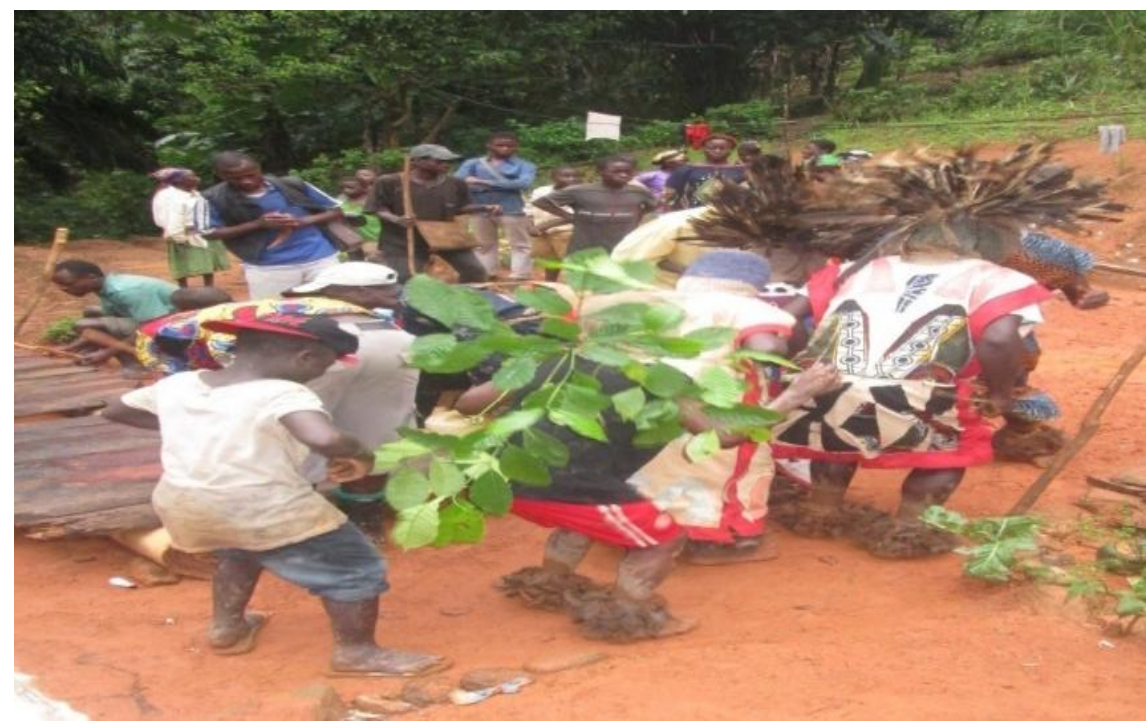

Source: author's collection, Valentine MonojiElize, Bafui-Mbekunyam, September 11, 2017.

The picture above illustrates a traditional dance group constituted by youths from Beba and Bombe at a funeral in Bafui, Mbekunyam.

Generally, songs in Beba and Bombe was a way of expressing deep feelings. This was because when one cried, songs came out and when one sang one lamented. Thus, the themes of songs were as varied as the type of songs. During this occasion the researcher caught up with several indigenes from Bombe who had come to commemorate the departure of their loved one. Among others was Agha Fonki who stated that the deceased was his uncle. He indicated that his parents were in Bombe, but he had a compound and piece of land in Beba. ${ }^{45}$

One of the most remarkable occasions that pulled Beba and Bombe people together occurred in 1980, following the death of FondehAghanifor the fourth ruling Fon of Beba. Frederick Mome indicated that he was in Bombe when the incident occurred and by his observation almost everybody who was healthy went to Beba. He emphasized that just a few persons including himself, the Fon and a few aged people in the community stayed behind because they could not trek.

\section{BEDECA: RESCUING DEVELOPMENTAL CHALLENGES IN BEBA AND BOMBE}

The Beba Development and Cultural Association (BEDECA) was formed in 1985 basically to strengthen ties between Beba and Bombe and by extension, forgesocio-economic development and enhance the cultures of these communities. Beba and Bombe were peripheral localities within their Sub-Divisions. These communities had very poor road networks which retarded the smooth circulation of goods and persons. Health units were generally non-existent. Thus, those who encountered severe health challenges had to move to other areas where they could be given medical attention. The result was that some of the critically ill died before reaching the hospital especially asthey had to be transportedonraffia bamboos.

Equally, educational institutions were new absent. This necessitated pupils from both communities to move to faraway villages to study. Sadly enough, children whose parents were not financially upright could not go to school because of the costs involved. There was equally the absence of pipe borne water. People had to drink from local streams. The need to consolidate socio-cultural ties between Beba and Bombe and by extension promote socio-economic development therefore necessitated these people to come together under the umbrella of BEDECA. In response to the issue of transport communication, considerable efforts were made by BEDECA to construct the MuguBridge linking Beba and Okoromanjang. The entire Beba community was taxed, with each person paying at least five thousand Francs CFA (5000CFA) through the different BEDECA branches. ${ }^{46}$ For details on the bridge constructed by BEDECA see (picture III).

\footnotetext{
${ }^{45}$ Interview with FebertNgendo, Bombe, August 23, 2015. Farmer, age 82.

${ }^{46}$ Interview Frederick Mome, Mutengene, August 10, 2017. Farmer, age 92.
} 


\section{Picture III: the Mugu Bridge constructed by BEDECA in 1998}

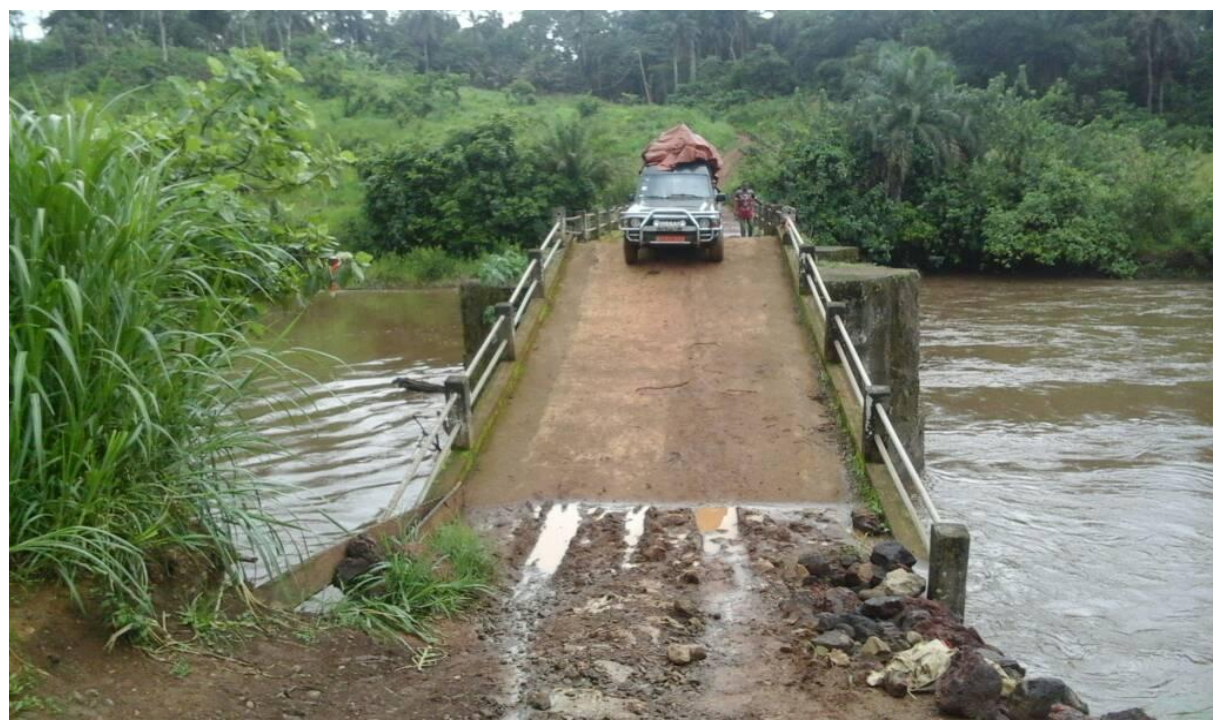

Source: Author's collection, Valentine ElizeMonoji, September 25, 2017.

The bridge above was constructed in the late 1990s across the River Mugu, linking Beba and Okoromanjang, a neighbouring village to Beba. Before the late 1990s when the construction work started vehicles could only stop at Okoromanjang and the rest of the journey was covered on foot. The absence of this bridge stood as the main impediment to the development of Beba. With its eventual construction easy movement of persons and goods in and out of Beba was guaranteed. In fact, the construction of this bridge was a remarkable success recorded by this association. BEDECA is equally credited for initiating and realizing various charged projects in Beba. This was the case with the supply of pipe-borne water, specifically at Mbamba, host to Beba Central market. ${ }^{47}$ Before the realization of this project, traders, especially those who came from Oshie, Meta and other faraway places encountered a lot of challenges having access to drinkable water. With the realisation of this project, traders, the people of Mbamba and by extension, the entire Beba community enjoyed access to pipe borne water.

The dreams of BEDECA were lofty and the intensions were clear but the very foundations for which the association was created were disrupted due to alleged antiquated practices of corruption and misappropriation of funds. It is stated that as the association increased in size and popularity, the management became excessively corrupt. Earmarked projects were not executed, and no proper accountability could be advanced regarding the use of funds. ${ }^{48}$ This left so many people disgruntled thereby making them less committed to the affairs of BEDECA. Thus, by 2007, the association had become a rubber stamp. It existed beyond 2007 but had very little or nothing to offer. ${ }^{49}$ Equally worthy of mention is the fact that at creation, BEDECA seemed in its objectives to be an association aimed at fostering the socio-economic development of Beba and Bombe, but that was not necessarily the case. This is explained by the fact that from its very inception to the period of recession, the organization had not realized a single project in Bombe.

\section{The Bekpopregulatory society: vector of unity}

It can be said that even though the Bombe people are found in Akwaya sub-Division in the South West Region of Cameroon, their institutions are fundamentally different from those of the neighbouring villages. Rather their regulatory societies have similar characteristics with those of the Beba people in Menchum Division of the North West Region. These institutions are same in terms of nomenclature, the role they perform and how they are organized. Aside others, the Bekpopsociety proved to be a seal bonding the two groups.

The early beginnings in socio-cultural relations between Beba and Bombe were inextricably linked to the activities of the Bekpopsociety. This institution is said to have started as a friendship pact between

\footnotetext{
${ }^{47}$ Interviews with Zebedee Fowoh, Mbekunyam, Fowoh, September 21, 2015. Farmer, age 64.

${ }^{48}$ Interview with Pius Awambeng, Upper Mbekunyam, September 10, 2017. Farmer, age 76.

${ }^{49}$ Interview with Zebedee Fowoh, Mbekunyam, September 21, 2015. Farmer, age 64.
} 
a medicine man from Beba and another from Meta. ${ }^{50}$ The body was fundamentally responsible for the enthronement and swearing in of a new Fon. ${ }^{51}$ Besides the burial and enthronement of a Fon, the Bekpop performed advisory functions to the Fon especially on intractable issues. In the strictest sense of traditional requirement this body is constituted by three main types of Bekpop or kingmakers in these communities: BekpopGeh, who are four in number, BekpopNdoutie, they are also four in number and lastly, the Bekpop Nshielah, equally four in number. Although all of them have equal status, distinct functions and rights are attributed to them. ${ }^{52}$

When the breakaway faction arrived at Bombe they were forced to constitute their own house of Bekpop and this was not different from what existed in Beba in terms of composition and the role that they performed in society. In both communities, membership into this society was strictly hereditary. The families remained same and if a family was not a member, it could not be initiated. Unfortunately, the BekpopGeh was not found in Bombe. Also, in these communities, certain calamities were considered anomalous and spiritually instigated. This was particularly the case with enigmatic death, known as "abere". ${ }^{53}$ These included: murder cases, any form of suicide, where a man drowned, death by falling off a palm tree, motor accident, among others. These were considered as acts that needed cleansing. In Beba, the BekpopGeh, were those entrusted the powers to handle cases of abere. Regrettably, this body was completely absent in Bombe. ${ }^{54}$

It is important to note that the Bekpopis an embodiment of the different families that constitute the Beba community. This families include: the BafihNekro which is made of Bangoh, Baro, Bafih; the Banjir, made up of BantahBonefeh, Bafuke, MbentiBengesoh, Befui, Batobeh, Boyiko, Botaka; the Batollah, made up of the Bomah, Boyibo, BoadiehYiboh, Bodestere, Bazo, Bodieh, Bomeko, Bodoh; and the Bantrallah who are the Besongwere, Besongui, Boyitswe and Boyikah. ${ }^{55}$ All the members of a nekroare not necessarily agglomerated in a geographical location- the various families are spread throughout Beba and in other parts of Cameroon, but the people know their nekro(family lines) and stick to them especially for family rituals, public negotiations and cultural celebrations. ${ }^{56}$

It should be recalled that the first settlers at Bombe were entirely princes from Beba who fall within the category of the Batollah-royal family. It is true that in no distant time other members of the royal family and commoners in Bebabegan moving toBombe to settle and live with their kinsmen. But the existence of different segments of the Beba family lines in Bombe could not give them the BekpopGeh status because membership was strictly hereditary. ${ }^{57}$ Where a family in Bombe was faced with cases of abere it became non-negotiable for the matter to be reported to the Bekpop in Beba for cleansing. Cleansing was unavoidably necessary because the people believed that if it was not done the family would keep on experiencing similar grief-stricken situations. ${ }^{58}$

\footnotetext{
${ }^{50} \mathrm{Cb}$ 1932/1, Quarterly Reports on the Bamenda Division, Cameroons Province, i932-1933, NAB.,Interview with David Forba Agha, August 21, 2015. Farmer and member of the Bekpop society in Bombe, Aged 92.The story is told that a medicine man once invited his intimate friend to appreciate the long and good friendship that had existed between them. Since both were strong men, he proposed that they should trade their herbs as a symbol of goodwill. His friend agreed, and they did it on oath never to harm or even plot evil against one another. The host roasted a cock and split it into two equal halves. As the host he ate the gizzard and gave his guest the liver. They drank palm wine and parted. When this man later invited his friend to reciprocate his hospitality, the friend came with his brother whom they admitted. Soon, an assembly of strong medicine men in the tribe had been formed with the sole aim of eliminating rivalry and preventing strife. Hence, there was to be equality and mutual respect. They therefore agreed that total parity could only be achieved by empowering a neutral person and making him their leader. Thus, the first Fonwas crowned who was to be supreme to all the family groups in the tribe.

${ }^{51}$ Interview with David Forba Agha, August 21, 2015. Farmer and member of the Bekpop society in Bombe, Aged 92.

${ }^{52}$ Ibid.

${ }^{53}$ Interview with Daniel Njowa, Bombe, August 22, 2015. Farmer, age 91.

${ }^{54}$ Interview with Beatrice Abinyam, Bombe, August 22, 2015. Farmer, age 62.

${ }^{55}$ Nfah-Abbenyi, Makuchi, The Sacred Door and other Stories:Cameroon Folktales of the Beba(Ohio:Ohio University Press, 2008), 191.

${ }^{56}$ Ibid.

${ }^{57}$ Interview with David Forba Agha, August 21, 2015. Farmer and member of the Bekpop society in Bombe, Aged 92.

${ }^{58}$ Interview with Pius Awambeng, Upper Mbekunyam, September 10, 2017. Farmer, age 76.
} 


\section{Egg oath: strains in Beba-Bombe relations}

In 1993, the people who constitute the Beba and Bombe communities, with much consciousness of their common roots decided to establish a formal relationship that would bring them together ones every year, under the umbrella of the Cultural Week Celebrations. The rich cultures that were exercised by these people before the segmentation were neither substituted nor adulterated by the Bombe people during their migration. These cultural values were preserved and kept intact. Thus, the Cultural Week exhibitions were organised with participation strictly limited to the Beba and Bombe people.

These cultural festivities were to recuperate and brace the relations between the two groups. From the inception of the program, the main hosting community was Beba. The occasion was organized yearly in the month of December at Fombe, one of the villages in Beba. It was a program that embodied several fascinating activities. There were football and handball matches, cultural displays in the form of singing and dancing, just to name but these. Beba hosted the program uninterrupted until 2006 when Bombe equally indicated interest to host. According to the 2016 end-of-activities negotiations, it was unanimously accepted that Bombe would host in 2007 with a precondition that the Fon of Beba, Henry Angobo II would answer present. ${ }^{59}$

Aware of the egg oath and the associated dangers, the Bekpop(kingmakers) press-ganged Angobo II to turn down the invitation.The failure of FonHenry Angobo II to honour the invitation emasculated the flourishing Cultural Week Celebrations. It was widely believed that any of the Fonsbe it that of Beba or Bombe who for whatsoever reason stepped his leg on the soil of the other community would die.The year 2007 was therefore a watershed in the cultural exhibitions between Beba and Bombe. This is because the presence of the Fon of Beba in Bombe would have served as a pre-requisite for the continuation of the cultural festivities between the two groups.

\section{CONCLUSiON}

This paper has examined the relations between Beba and Bombe from a socio-cultural prism.The study submits that in the eight decades of segmentation the relations between the two communities was guided largely by ancestral leanings and traditional demands.Although separated for more than eight decades, they never remained unsighted to their coresocio-cultural values and sense of belonging. It is against this awareness of a common ancestry and the dire need to resolve frightening traditional demands that considerable efforts were made to consolidate their ties. This manifesteditself in intermarriages, removal of the strings imposed by the egg oath, promotion of joint cultural festivities, and the establishment of BEDECA. These among other things have created a bond that has kept their relations very close.Although these efforts were sometimes met with hard barriers, evidently, the people have succeeded in consolidating a bond that would for centuries not be terminated.

\section{REFERENCES}

[1] Abinyam, Beatrice. Bombe, August 22, 2015. Farmer, age 62.

[2] Agha, David Forba. August 21, 2015. Farmer and member of the Bekpop society in Bombe, Age 92.

[3] Agha, Isaiah. Bombe, August 22, 2015. Farmer, age 88.

[4] Agha, Patrick Nkwenti. Mbekunyam, September 22, 2015. Farmer, age 60.

[5] Angobo, Henry Fondeh. Beba, September 20, 2015. Fon of Beba, age 44.

[6] Awambeng, Pius. Upper Mbekunyam, September 10, 2017. Farmer, age 72.

[7] Fonki, Alphonse. Mbekunyam, September 12, 2015. Farmer, age 75.

[8] Forba, Beatrice. Bombe, August 23, 2015. Farmer, age 62.

[9] Forba, Gabriel Abinyam. Bombe, August 20, 2015. Farmer and member of the Bekpopsociety in Bombe, age 94.

[10] Forba, William. Bamenda, January 20, 2018. Teacher, age 58.

[11] Fowoh, Zebedee. Mbekunyam, September 21, 2015. Farmer, age 64.

[12] Mangoh, Daniel. Bombe, August 20, 2015. Farmer and member of kpeifor Society in Bombe, age 83.

\footnotetext{
${ }^{59}$ Interview with David Forba Agha, August 21, 2015. Farmer and member of the Bekpop society in Bombe, Aged 92.
} 
[13] Monoji, Joseph. Bombe, August 22, 2015. Farmer, age 84.

[14] Monoji, Peter. Konge, September 5, 2018. Farmer, age 76.

[15] Mundi, Regina. Bombe August 23, 2015. Farmer, age 76.

[16] Ngendo, Febert. Bombe, August 23, 2015. Farmer, age 82.

[17] Ngendo, Mary. Bombe, August 21, 2015. Farmer, age 84.

[18] Njowa, Daniel. Bombe, August 22, 2015. Farmer, age 91.

[19] Nyambi, Anthonia. Bombe, August 24, 2015. Farmer, age 86.

[20] Tibah, Margaret. Bombe, August 21, 2015. Farmer, age 82.

[21] Archival Sources from the National Archives Buea(NAB)

[22] Ad 17, file no.4583A, Assessment report on the Wum Native Authority Area of Bamenda Division, 1932, (NAB).

[23] Ad 19, file no. 3434, Report on the Reorganization of the WumBefang and Beba tribes in the Wum Native Authority Area Bamenda Division, 1934, National Archives Buea.

[24] Cb 1932/1, Quarterly Reports on the Bamenda Division, Cameroons Province, 1932-1933.

[25] Cb 1934/1, Annual ReportBamenda Division 1934-1945.

[26] File no. 772/22, Wum Assessment Report, 1932.

[27] File no. D 1270/s.4, Administrative Re-organization Akwaya Sub District, 1963. Secondary Sources

[28] Dillon, R. G. "Ideology, Process and Change in Precolonial Meta Political Organisation (United Republic of Cameroon)". PhD Thesis, University of Pennyslvannia, 1973.

[29] Fanso, V.G. Cameroon History for Secondary Schools and Colleges Vol. 2: The Colonial and PostColonial Periods. London: Macmillan Education Books, 1989.

[30] Gatawa, Muhammad Mukhtar. " Inter-group Relations in Historical Perspectives: A Case Study of Yoruba andHausa communities of Agege, Lagos, Nigeria". African Journal of History and Culture 5, No. 9 (2013): 111-126.

[31] Makuchi, Nfah-Abbenyi. The Sacred Door and other Stories: Cameroon Folktales of the Beba. Ohio:Ohio University Press, 2008.

[32] Ndeh, GraceNgwebi. "Communicative and Educative Devices in a Traditional African Society: The case of Beba”.MA dissertation, University of Buea, 2002.

[33] Nkwi, P. N. Traditional Diplomacy: A Study of Inter-Chiefdom Relations in the Western Grassfields, North West Province of Cameroon. Yaounde: 1987.

[34] Nyamndi, Ndifontah B. The Bali Chamba of Cameroon: A Political History. Paris: Edition Cape, 1988.

[35] Smith, R. S. Warfare and Diplomacy in Precolonial West Africa. Norwich: Metheun and Co., 1976.

[36] Warnier, J. P. "Precolonial Mankon: The Development of a Cameroon Chiefdom in its Regional Setting". PhD Thesis, University of Pennysylvania, 1975.

\section{AUTHOR'S BIOGRAPHY}

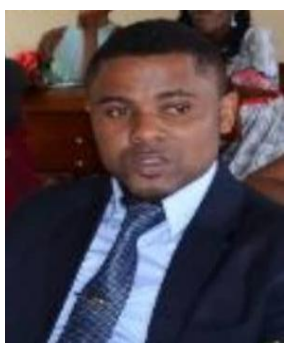

Valantine Elize Monoji, obtained his Bachelor's and Master's Degrees from the University of Buea, Cameroon, after which he proceeded to Higher Teacher Training College Bambili, where he obtained a Secondary School Teacher Diploma II. He is currently pursuing a $\mathrm{PhD}$ at the University of Bamenda, Cameroon. He has vested interest in aspects of economic and social history.

Citation: Valantine Elize Monoji. “Beba-Bombe Relations: A Study in Socio-Cultural Ties Between Distant Sister Chiefdoms, 1934-2007” International Journal of History and Cultural Studies (IJHCS). vol 6, no. 2, 2020, pp. 27-38. doi: DOI: http://dx.doi.org/ 10.20431/2454-7654.0602004.

Copyright: (c) 2020 Authors. This is an open-access article distributed under the terms of the Creative Commons Attribution License, which permits unrestricted use, distribution, and reproduction in any medium, provided the original author and source are credited. 